\title{
Calibration and application of the MN2D dynamics model to the avalanches of Las Leñas (Argentina)
}

\author{
M. Naaim ${ }^{1}$, G. Furdada ${ }^{2}$, and H. Martínez ${ }^{3}$ \\ ${ }^{1}$ Division ETNA, CEMAGREF, 2 Rue de la papeterie. BP 76, F-38402 Saint-Martin-d'Hères cedex, France \\ ${ }^{2}$ Dept. Geodinàmica i Geofísica, Universitat de Barcelona, Martí i Franquès s/n, E-08028 Barcelona, Spain \\ ${ }^{3}$ IDEPRN, Universidad Nacional de Cuyo - CONICET, Centro Universitario, C.C. 405, 5500 Mendoza, Argentina
}

Received: 20 September 2001 - Revised: 13 March 2002 - Accepted: 15 March 2002

\begin{abstract}
During the winters of 1999 and 2000 large avalanches occurred in the ski resort of Las Leñas (Los Andes, Mendoza, Argentina). On 8 September 1999 an avalanche of new, dry snow ran over a path with a $1000 \mathrm{~m}$ vertical drop. On 30 June and on 1 July 2000 five avalanches of similar vertical drop, which start with new snow, entrained very wet snow during their descent, and evolved into dense snow avalanches.

To use the MN2D dynamics model correctly, calibration of model parameters is necessary. Also, no previous works with the use of dynamics models exist in South America. The events used to calibrate the model occurred during the winters of 1999 and 2000 and are a good sample of the kind of avalanches which can occur in this area of the Andes range.

By considering the slope morphology and topography, the snow and meteorological conditions and the results of the model simulations, it was estimated that these avalanches were not extreme events with a return period greater than one hundred years. This implies that, in natural conditions, bigger, extreme avalanches could happen.

In this work, the MN2D dynamics model is calibrated with two different avalanches of the same magnitude: dry and wet. The importance of the topographic data in the simulation is evaluated. It is concluded that MN2D dynamics model can be used to simulate dry extreme avalanches in Argentinean Andes but not to simulate extreme wet avalanches, which are much more sensitive to the topography.
\end{abstract}

\section{Introduction}

Snow avalanche dynamics models had never been used in Argentina to simulate avalanches.

During the winters of 1999 and 2000 large avalanches occurred in the ski resort of Las Leñas (Los Andes, Mendoza, Argentina). On 8 September 1999 an avalanche of new, dry

Correspondence to: M. Naaim

(mohamed.naaim@grenoble.cemagref.fr) snow ran over on a path with a $1000 \mathrm{~m}$ vertical drop. On 30 June and on 1 July 2000 five avalanches of similar vertical drop, which start with new snow and entrained very wet snow during their descent, evolved into extremely dense avalanches. One of them started at the same location as the big dry avalanche in the previous 1999 episode and followed a similar path in the upper track zone (Furdada et al., 2000).

The two big avalanches that started at the same release area are treated in this study with the following objectives: (1) Try to calibrate the MN2D dynamics model with two different avalanches of the same magnitude: dry and wet; (2) Evaluate the importance of the topographic data in the simulation; (3) Evaluate whether the avalanches of 1999 and 2000 were extreme avalanche events; and (4) Evaluate whether MN2D dynamics model can be used to simulate extreme avalanches in Argentinean Andes.

\section{The site and the avalanches}

Las Leñas ski resort is located in the Argentinean Andes, Department of Malargüe, Province of Mendoza. The area where the resort is located has a minimum altitude of $2200 \mathrm{~m}$ a.s.l. The highest altitude corresponds to Cerro Fósiles (3430 m a.s.l.), at the top of a nearly flat plateau of about $1 \mathrm{~km}$ wide and more than $2 \mathrm{~km}$ length. This surface, exposed to the winds, dominates an East oriented slope with a vertical drop greater than $1000 \mathrm{~m}$. The top of the rocky slope is channelled, with well marked incisions that become progressively wide. The run-out zone is an open, unchanelled slope. Also, the natural channels have been modified to improve the ski runs. The avalanches considered in this work overran this slope.

The medium lower limit of seasonal winter snow in this region of the Andes is about 2400 to $2500 \mathrm{~m}$ a.s.l., though often, especially during snow storms it reaches 2200 to $2100 \mathrm{~m}$ a.s.l. It is a dry region, often affected by Zonda, a dry wind generated by foehn effect. The dominant winds are from Northwest, but due to a local effect the main direction over 
Cerro Fósiles and the flat plateau becomes West (C. Torres, chief of pistes, personal communication). These winds generate considerable snow accumulations at the top of the East facing slope.

The two large avalanches treated in this work occurred on 8 September 1999 (dry avalanche) and on 30 June 2000 (wet avalanche). Both occurred after some days of snow storms. The meteorological conditions and the main characteristics of snow cover and of both avalanches are sumarised below.

\subsection{Avalanche conditions on 8 September 1999}

The avalanche occurred at 08:00 $\mathrm{h}$ in the morning, after two episodes of heavy snowfalls. The first was from $29 \mathrm{Au}-$ gust to 1 September. It was followed by three days of variable weather and daily positive temperatures at $2250 \mathrm{~m}$ a.s.l. Temperatures did not descend below $0^{\circ} \mathrm{C}$ during the third to fourth night, so the snow cover stabilised. The second snowfall, which caused the avalanche, was from 5 to 8 September (Tables 1 and 2).

The snow of this episode was very dry and light (com. pers. of C. Torres, chief of pistes of Las Leñas and J. A. Vergara, Dept. of Geophysics, University of Chile: data from Lagunitas, $2670 \mathrm{~m}$ a.s.l., Central Chilean Andes. The observations are coherent due to the regional scale of the snowstorm). In Table 1 a summary of significant snow and meteorological conditions measured in Las Leñas at $2250 \mathrm{~m}$ a.s.1. is shown. Absolute maximum and minimum daily temperatures were not recorded. The snow depth measured in one slope gives an idea of the magnitude of the snowfall, though the snow was mechanically compressed and the measure is not representative of the total snow during the episode. It has to be pointed out that the decrease of temperature on 7 September and the morning of 8 September prevented the snow cover from stabilizing. The intense NW winds on the morning of 8 September (which, due to local topographic effects, had to be even more intense and from the West at the top of the East facing slope) also prevented the snow cover from stabilizing.

The great quantity of snow which fell at different altitudes during this episode is shown in Table 2. Neither settlement nor wind drift is taken into account in the total amount of measured snow.

The snow profile of Fig. 1 shows that $18 \mathrm{~h}$ before the avalanche, at $2415 \mathrm{~m}$ a.s.l. there was about $1 \mathrm{~m}$ of dry and very light snow. The temperature profile shows the gradient, which increased the next day (Table 1), most probably maintaining the quality of the snow and minimising the settlement.

All these data support the conclusion that the dry snowfall and the intense wind transport produced snowdrifts in the channels at the top of the considered slope. At the same time, the whole slope was covered by a very light snow cover which could be easily eroded and entrained by the avalanche.

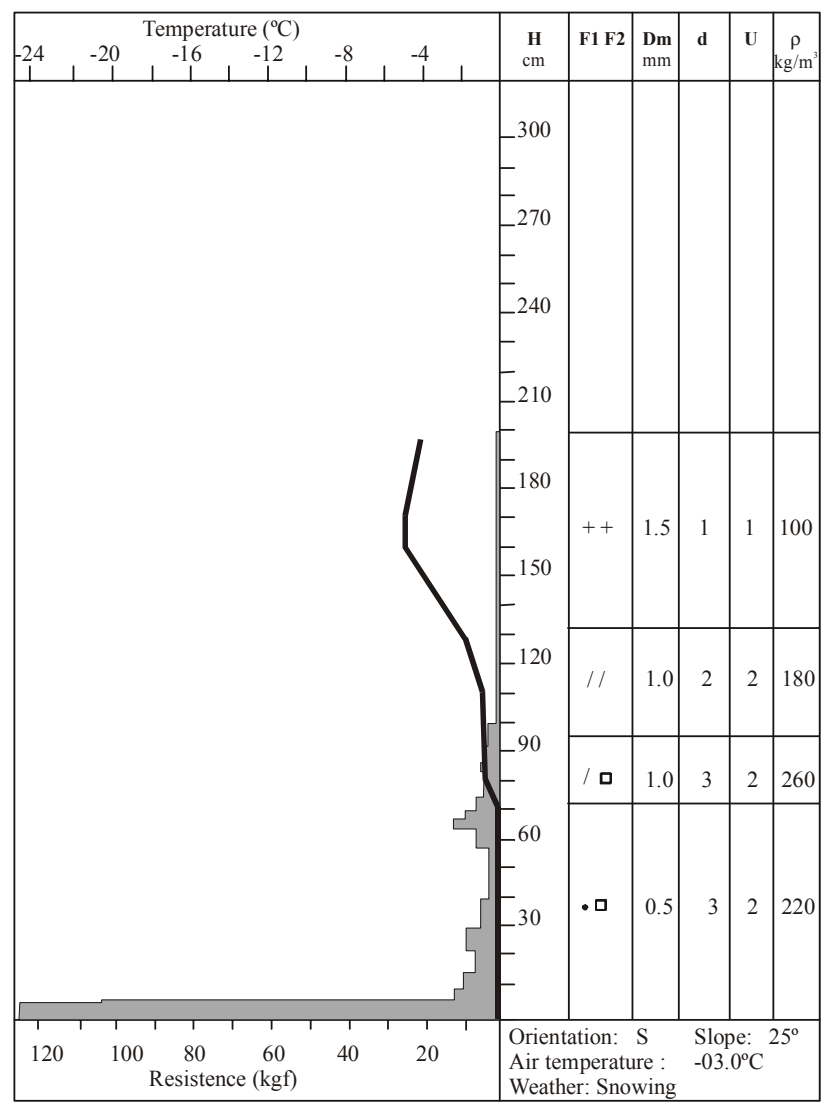

Fig. 1. 7 September 1999: Las Leñas snow profile (2415 m a.s.1.) at $12: 00 \mathrm{~h} . \mathrm{H}(\mathrm{cm})$ is the height of the snow above the ground in $\mathrm{cm}$; F1 F2, form of the snow grains, the symbols are in accordance with international classification standards; Dm, diameter of the snow grains; $d$, hardness of the snow layer (qualitative measure); $\mathrm{U}$, water content in the snow layer (qualitative measure); $\rho$, density of the snow layer.

\subsection{Avalanche conditions on 30 June 2000}

The avalanche occurred at 19:00 h, after 17 days of snowstorms and strong winds (C. Torres and G. Chiguay, com. pers.). The last episode began on 27 June and finished on 30 June (Tables 3 and 4). In Table 3, a summary of significant snow and meteorological conditions measured at $2250 \mathrm{~m}$ a.s.l. is shown. Absolute maximum and minimum daily temperatures were not recorded. The snow depth measured at a location gives an idea of the snow settlement and melting that began on 29 June as a result of the rain and positive temperatures. However, the snow was mechanically compressed and the measure is not representative of the natural snow cover.

On 30 June, during all the day, the $0^{\circ} \mathrm{C}$ isotherm remained at $2600 \mathrm{~m}$ a.s.l. and below this altitude it rained the entire day (G. Chiguay, com. pers.). This fact is not reflected in Table 4, where snow precipitation was not recorded on the days of 29 and 30 June due to the bad weather. Liquid precipitation is not recorded in the meteorological station. There are not snow profiles from this episode. On 30 June at 19:00 h the 
Table 1. Snow and meteorological conditions ${ }^{(1)}(2250 \mathrm{~m}$ a.s.1.)

\begin{tabular}{lllll}
\hline Day & $05 / 09 / 1999$ & $06 / 09 / 1999$ & $07 / 09 / 1999$ & $08 / 09 / 1999$ \\
\hline$T$ range (08:00-18:00 h) & $0.9^{\circ}$ to $-0.4^{\circ}$ & $0.7^{\circ}$ to $-2.2^{\circ}$ & $-3.2^{\circ}$ to $-5.1^{\circ}$ & $-7^{\circ}$ \\
Snow quality & Dry & Dry & Very dry & Very dry \\
Snow depth (in piste) & $0.80 \mathrm{~m}$ & $0.95 \mathrm{~m}$ & $1.15 \mathrm{~m}$ & $1.30 \mathrm{~m}$ \\
Snow precipitation & $0.40 \mathrm{~m}$ & $0.41 \mathrm{~m}$ & $0.70 \mathrm{~m}$ & $0.20 \mathrm{~m}$ \\
Wind & Variable & Variable & NE & $\mathrm{NW}$ \\
& Low intensities & $12: 00 \mathrm{~h}: 21 \mathrm{~m} / \mathrm{s} \mathrm{SW}$ & All day: $6-11 \mathrm{~m} / \mathrm{s}$ & $08: 00 \mathrm{~h}: 20 \mathrm{~m} / \mathrm{s} \mathrm{NW}$
\end{tabular}

(1) Temperatures were measured at $08: 00 \mathrm{~h}, 10: 00 \mathrm{~h}, 12: 00 \mathrm{~h}, 15: 00 \mathrm{~h}$, and 18:00 h. Temperature ranges correspond to the maximum and minimum of these 5 measures. Snow precipitation corresponds to the total snow fallen at the end of the day (18:00 h), except for $8 \mathrm{September}$, that corresponds to $08: 00 \mathrm{~h}$.

Table 2. Daily snow precipitation accumulated until 18:00 $\mathrm{h}^{(2)}(\mathrm{m})$

\begin{tabular}{llllllll}
\hline Day (Sept. 1999) & 3 & 4 & 5 & 6 & 7 & 8 & total \\
\hline Base (2250 m a.s.l.) & 0 & 0 & 0.40 & 0.41 & 0.70 & 0.20 & 1.71 \\
Bacus (2600 m a.s.l.) & 0 & 0 & 0.75 & 0.53 & 0.84 & 0.30 & 2.42 \\
Bora Bora (3400 m a.s.l.) & 0 & 0 & 0.90 & 0.64 & 0.90 & 0.38 & 2.82 \\
Minerva B. (2290 m a.s.1.) & 0 & 0 & 0.60 & 0.37 & 0.65 & 0.20 & 1.82 \\
\hline
\end{tabular}

(2) Data of 8 September corresponds to 08:00 h.

snow cover below $2600 \mathrm{~m}$ a.s.l. was saturated with water (G. Chiguay, com. pers.) and, in consequence, presented a very low cohesion and was easily entrained by the avalanche.

\subsection{The avalanches}

All the previous data, the indications of the ski resort personnel, the observed damages after the avalanches and expert criteria were used to define the avalanches (Figs. 2 and 3). Settlement, according to the different meteorological conditions, wind drift and slope angle were considered to estimate snow fracture heights for both avalanches.

The avalanche on 8 September 1999 presented the following characteristics:

- It was a dry avalanche; snow entrainment increased the mass of the avalanche considered.

- The avalanche developed two flowing "tongues" and an important powder part.

- The estimated fresh snow accumulation at $2400 \mathrm{~m}$ a.s.1. was of about $1.10 \mathrm{~m}$.

- The estimated avalanche snow height fracture (at $3250 \mathrm{~m}$ a.s.1.) was about $1.50 \mathrm{~m}$.

- The snow density at $2400 \mathrm{~m}$ a.s.l. was the following: $0.40 \mathrm{~m}$ of $180 \mathrm{~kg} / \mathrm{m}^{3}$ plus $0.70 \mathrm{~m}$ of $100 \mathrm{~kg} / \mathrm{m}^{3}$.

- The estimated average snow density at fracture was $100 \mathrm{~kg} / \mathrm{m}^{3}$.
- The estimated average snow depth that could be entrained, (approx. from $3000 \mathrm{~m}$ a.s.1. to $2300 \mathrm{~m}$ a.s.1.) was about $1 \mathrm{~m}$ of snow with a density of $100 \mathrm{~kg} / \mathrm{m}^{3}$.

The avalanche on 30 June 2000 presented the following characteristics:

- The isotherm of $0^{\circ} \mathrm{C}$ was at $2600 \mathrm{~m}$ a.s.l. during all the day. Below this altitude it rained the entire day.

- The estimated avalanche snow height fracture (at $3250 \mathrm{~m}$ a.s.1.) was approximately $1.30 \mathrm{~m}$ to $1.50 \mathrm{~m}$.

- The estimated average snow density at fracture was between 150 and $180 \mathrm{~kg} / \mathrm{m}^{3}$.

- The avalanche developed a powder part at the beginning (2850 $\mathrm{m}$ a.s.1.), above the saturated snow limit of $2600 \mathrm{~m}$ a.s.1.

- The avalanche reached very wet snow at $2600 \mathrm{~m}$ a.s.1., entrained very wet snow and changed to a very wet avalanche. It developed two very wet "tongues" that adapted very well to the topography.

- The estimated average snow depth that could be entrained from $2600 \mathrm{~m}$ a.s.l. to lower altitudes was of about $0.80-1.00 \mathrm{~m}$.

- The estimated density of the very wet snow entrained below $2600 \mathrm{~m}$ a.s.1. was greater than $450 \mathrm{~kg} / \mathrm{m}^{3}$.

The damages produced by both avalanches are indicated in Figs. 2 and 3.

\section{Calibration of the MN2D model}

\subsection{The model}

Naaim and Ancey (1992) equations for the motion of the dense component of an avalanche in two dimensions are 
Table 3. Snow and meteorological conditions ${ }^{(3)}$ ( $2250 \mathrm{~m}$ a.s.1.)

\begin{tabular}{lllll}
\hline Day & $27 / 06 / 2000$ & $28 / 06 / 2000$ & $29 / 08 / 2000$ & $30 / 06 / 2000$ \\
\hline$T$ range (08:00-18:00 h) & $-3^{\circ}$ to $-1^{\circ}$ & $-5^{\circ}$ to $-2^{\circ}$ & $-1^{\circ}$ to $+3^{\circ}$ & $+1^{\circ}$ to $+2^{\circ}$ \\
Snow quality & Dry & Dry & - & Very wet \\
Snow depth (in piste) & $1.00 \mathrm{~m}$ & $1.35 \mathrm{~m}$ & $1.55 \mathrm{~m}$ & $1.25 \mathrm{~m}$ \\
Snow precipitation & $0.89 \mathrm{~m}$ & $0.18 \mathrm{~m}$ & $<0.05 \mathrm{~m}$ & Snow and rain \\
Wind & ESE & Variable. & Variable. & Variable \\
& Low intensities & Low intensities & $08: 00 \mathrm{~h}: 19 \mathrm{~m} / \mathrm{s} \mathrm{NW}$ & $08: 00 \mathrm{~h}: 14 \mathrm{~m} / \mathrm{s} \mathrm{NE}$ \\
\hline
\end{tabular}

(3) Temperatures were measured at 08:00 h, 10:00 h, 12:00 h, 15:00 h, and 18:00 h. Temperature ranges correspond to the maximum and minimum of these 5 measures. Snow precipitation corresponds to the total snow fallen at the end of the day $(18: 00 \mathrm{~h})$.

Table 4. Daily snow precipitation accumulated until 18:00 $\mathrm{h}^{(4)}(\mathrm{m})$

\begin{tabular}{llllllll}
\hline Day (June 2000) & 25 & 26 & 27 & 28 & 29 & 30 & total \\
\hline Base (2250 m a.s.l.) & 0.10 & 0 & 0.89 & 0.18 & - & - & $>1.17$ \\
Bacus (2600 m a.s.l.) & 0.60 & 0 & 1.00 & 0.25 & - & - & $>1.85$ \\
Bora Bora (3400 m a.s.l.) & 0.60 & 0 & 1.00 & 0.35 & - & - & $>1.95$ \\
Minerva B. (2290 m a.s.l.) & 0.35 & 0 & 0.90 & 0.22 & - & - & $>1.47$ \\
\hline
\end{tabular}

${ }^{(4)}$ The lines (-) mean that no data were taken because of the bad weather.

based upon the shallow water equations. In Naaim and Ancey's model, the following general expression for the friction term is adopted:

$\tau=\tau_{0}+\rho_{d} g h \cos \theta \tan \varphi+a\left\|\bar{u}_{d}\right\|+b\left\|\bar{u}_{d}\right\|^{2}$.

With this general approach, several kinds of rheological behaviour can be readily incorporated. For example, a Bingham fluid (parameters $\tau_{0}$ and $a$ ), a granular fluid with Coulomb-type friction (bed friction angle $\varphi$ ), or a VF (parameters $\varphi$ and $b$ ) can all be expressed using this approach. Substituting (1) into the equations for the conservation of mass and momentum yields:

$\frac{\partial h}{\partial t}+\frac{\partial h u}{\partial x}+\frac{\partial h v}{\partial y}=0$

$$
\begin{aligned}
& \frac{\partial}{\partial t}\left(\begin{array}{l}
h u \\
h v
\end{array}\right)+\frac{\partial}{\partial x}\left(\begin{array}{l}
h u^{2} \\
h u v
\end{array}\right)+\frac{\partial}{\partial y}\left(\begin{array}{l}
h u v \\
h v^{2}
\end{array}\right)+\left(\begin{array}{l}
\partial_{x} \\
\partial_{y}
\end{array}\right) \\
& \left(\frac{1}{2} k g \cos \theta \cdot h_{2}\right)=-g h\left(\begin{array}{l}
\cos \theta_{x} \\
\cos \theta_{y}
\end{array}\right)-\frac{1}{\left\|\bar{u}_{d}\right\|}\left(\begin{array}{l}
u \\
v
\end{array}\right) \frac{\tau}{\rho_{d}}
\end{aligned}
$$

where $h$ is flow depth $\bar{u}_{d}=(u, v)^{t}$ the dense flow velocity, $\theta_{x}$ and $\theta_{y}$ are the terrain slope angles in the $x$ and $y$ directions, and $k$ the active-passive pressure coefficient.

The above system of equations is solved using a finite element method on a mesh consisting of quadrilateral elements placed a digitised terrain model. The elevation of the nodes of this irregular mesh is determined and the mean slope and orientation of each element are computed. The numerical flux through each edge is then determined using a simplified Riemann solver (Naaim, 1991).

\subsection{DTM used}

To apply the MN2D model to Las Leñas avalanche paths a digital terrain model (DTM) was generated. The original topographic map (scale 1:5000; distance between contour lines of $10 \mathrm{~m}$; made by Ecosign: Mountain Resort Planners Ltd., in 1992) was digitised. Contour lines were codified (altitude was assigned to each line). To obtain the best DTM, ArcInfo TINs (Triangulated Irregular Network models) were generated. Talwegs and dicks were used as breaklines (which define edges of triangles and force the DTM to maintain as much as possible the irregularities of the relief). Some DTMs were generated with different point simplifications along the contour lines in order to find the distance between points that create the minimum artifacts in the TIN DTM.

The best resulting TIN was transformed to an ArcInfo Lattice of $3 \times 3 \mathrm{~m}$ square cell. This resolution seemed to create few errors when compared to the original topographic map. This $3 \times 3 \mathrm{~m}$ square cell Lattice was exported to an ASCII file to be used for the MN2D dynamics model.

The resolution of the final DTM is limited by the quality of the original map. Also, interpolations applied in order to obtain the $3 \times 3$ cell Lattice result in real topography simplifications because original data have less resolution than the final DTM.

\section{Results}

The MN2D dynamics model was calibrated taking into account the well known run-out distances of both dry and wet avalanches. The results obtained are shown in Figs. 2 and 3.

When evaluating whether the observed avalanches can be thought of as extreme or not, first we consider that there were two large avalanches in two consecutive seasons. Though it is possible that two extreme avalanches occur in this short lapse of time, it has to be kept in mind that Las Leñas ski resort was built less than twenty years ago, so there is not a 


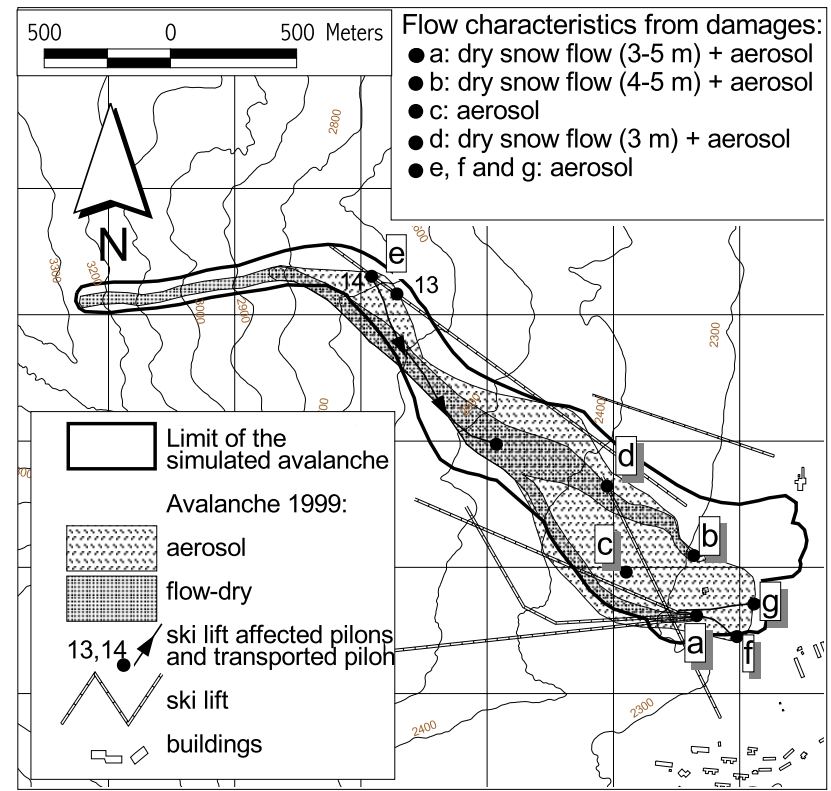

Fig. 2. Map of the dry avalanche of 8 September 1999. Observations and simulation.

long historic register of avalanches that could support these magnitude avalanches had not occurred before. In a first approach, it could be thought that the observed avalanches had a return period shorter than centenary.

On the other hand, we have found that Lied and Bakkehoi (1980), Salm et al (1990) or Mears (1992), the slope angles where the extreme avalanches are considered to begin to decelerate range approximately from $15^{\circ}$ to $8.5^{\circ}$, and they stop at lower angle slopes. The studied avalanches stopped at slope inclinations between $10^{\circ}$ and $15^{\circ}$. This fact and the smooth terrain made us think that larger avalanches could occur.

Finally, MN2D dynamics model was recently calibrated by using some well known extreme avalanches from different European paths (Barbolini et al, 2000). The basal Coulomb friction coefficient $\mu$ used to calibrate Las Leñas dry avalanche does not reach the value used to calibrate the European avalanches. From all these we deduce that the avalanches occurred in Las Leñas are not extreme avalanches.

\section{Conclusions and perspectives}

The first and obvious remark is that some knowledge of the region and information obtained from the personnel of the ski resort were absolutely necessary. In countries in development (and in some places also in developed countries), snow and meteorological data are not always complete nor are they completely representative of the avalanche conditions. All the data (specially the qualitative) must be treated carefully by experts. Otherwise, important mistakes can be made when using models.

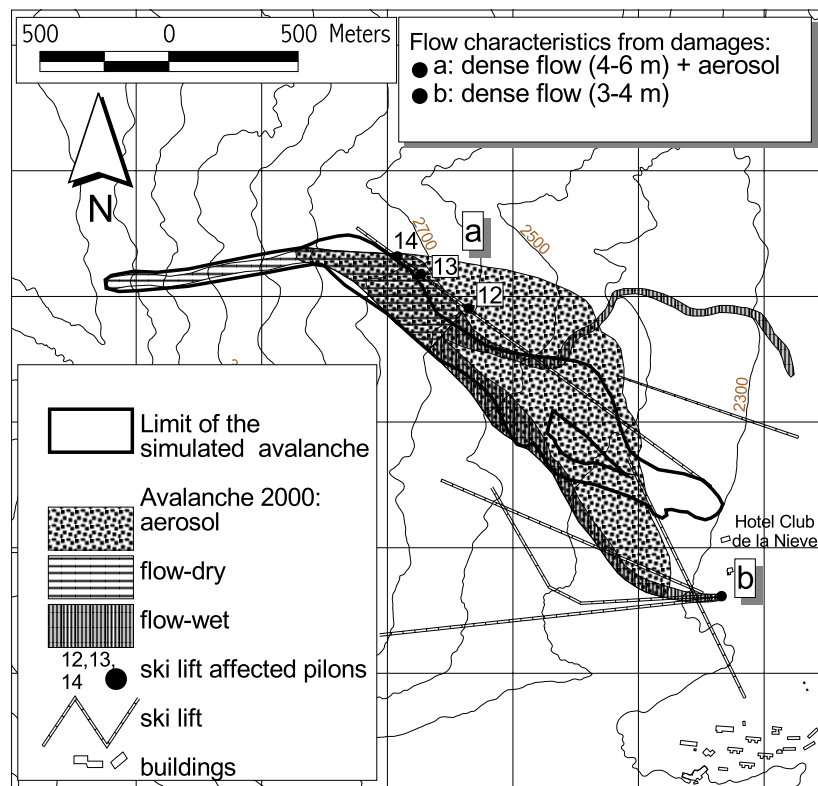

Fig. 3. Map of the mostly dry avalanche of 30 June 2000. Observations and simulation.

The MN2D dynamics model reproduces very well the extension of the dry avalanche. The avalanche mapped in Fig. 2 was reconstructed by using photographs and considering the damage, so it is possible (and also probable) that the aerosol was a little bit greater than mapped. We think the simulation probably improves the limits of the aerosol where there are no facilities or other references to appreciate the damage and so, to map the limit of the avalanche.

The model does not reproduce the wet avalanche, which is more sensitive to topographic features, well. The reasons could be: (1) The DTM is not good enough due the quality of the original map. (2) The DTM does not include the changes on the topography due to the snow cover (ski resort personnel piled snow building dikes to avoid the avalanches to reach the hotel. They modified the topography strongly and therefore the path of the avalanche). (3) The physics used in this model (viscoplastic model) need to be improved. (4) All previous reasons put together.

The studied avalanches were not catastrophic avalanches. The good simulation obtained for the dry avalanche suggests that the dry extreme avalanche can be simulated in short. The special case of an extreme wet avalanche, more sensitive to the topography and suggestive of heavy snowfalls followed by sharp temperature increase and rain, should be considered carefully, both without modification of the topography and with modification of the topography due to the snow piled by the ski resort. This ski resort decision and actuation must be considered right in order to protect the hotel. If definitive modification were performed and dikes built, they should be surveyed and a new topographic map should be provided to facilitate modelling of extreme avalanches.

Acknowledgements. We want to thank the financial suport of the 
following enterprises and institutions: Las Leñas Ski resort; ACI 99-18 Generalitat de Catalunya; Secretaría de Ciencia y Técnica Universidad Nacional de Cuyo; CUR: 1999SGR00065; Division ETNA-Cemagref. We want also thank the collaboration of C. Torres, chief of pistes and G. Chiguay from Las Leñas, and T. Moyano from the Servei de Dibuix UB.

\section{References}

Barbolini, M., Gruber, U., Keylock, C.J., Naaim, M., and Savi, F.: Application of statistical and hydraulic-continuum dense-snow avalanche models to five real European sites, Cold Reg. Sci. Tech., 31, 133-149, 2000.

Furdada, G., Martínez, H., Leiva, J. C., and Foerster, M.: Reducción del riesgo de avalanchas de nieve: el ejemplo de la estación de esquí de Las Leñas, Actas XXa Reunión Científica de Geofísica y Geodesia de la Asociación Argentina de Geofísica y Geodesia (AAGG), 264-268, 2000.

Lied, K. and Bakkehoi, S.: Empirical calculations of snowavalanche run-out distance based on topographic parameters, J. of Glaciol., 26:94, 165-178, 1980.

Mears, A.: Snow-Avalanche hazard analysis for land-use planning and engineering, Colorado Geological Service Colorado, 49, 55, 1992.

Naaim, M.: Modélisation numérique effets hydrodynamiques produit par un glissement solide dans une retenue de barrage, $\mathrm{PhD}$ thesis, Joseph Fourier University, Grenoble, 180, 1991.

Naaim, M. and Ancey, C.: Dense avalanche model, European Summer University, Chamonix, Cemagref, 173-181, 1992.

Salm, B., Burkard, A., and Gubler, H. U.: Calcul des Avalanches: Une méthode pour le practicien avec des examples, IFENA, 47, 38,1990 . 